\title{
THE DUTIES AND CONFLICTS OF NOMINEE DIRECTORS: THE LEGAL POSITION IN MALAYSIA
}

\author{
Kamaliah Salleh", Mohd Fuad Husaini, Asiah Bidin, Noraida Harun, Noor 'Ashikin Hamid \\ Faculty of Law and International Relations,Universiti Sultan Zainal Abidin 21300 Terengganu, Malaysia, \\ kamaliahsalleh@unisza.edu.my* (Kamaliah Salleh) \\ mohdfuad@unisza.edu.my_(Mohd Fuad Husaini) \\ asiah@unisza.edu.my (Asiah Bidin) \\ noraida@unisza.edu.my (Noraida Harun) \\ shikin@unisza.edu.my (Noor ‘Ashikin Hamid)
}

\begin{abstract}
There are different factors and basis for appointment of directors in a company's board. Some of them are appointed based on their expertise in the respective sectors or industries as independent directors in the board, while others may be appointed by creditors or major shareholders or interest group as nominee director. Just like all directors, nominee directors are expected to act in the best interests of the company to which they are appointed. Further, they also owe the same legal fiduciary duties to the company similar to other directors. Nominee directors bears additonal expectation as they do not only manage and perform in the company's board, but they are commonly expected by their appointers to represent the interest of the appointers in any commercial decisions made by the board of the company and also to update the appointers on the company's performance from time to time. The objective of this paper is to study the duties owed by nominee directors in the event of conflicts of interest that possibly occurs between the company where they are sitting as board members and their appointers. The study will focus on the law governing them in Malaysia. This research adopted qualitative analytical method in which books, article journals, internet sources and other relevant documents are analysed. It was found that it is very crucial for the nominee directors to observe certain rules pertaining to their duties and involvement in decision making in order to mitigate such conflicts.
\end{abstract}

Keywords: Nominee Directors, Duty, Conflicts

Article Received: 18 October 2020, Revised: 3 November 2020, Accepted: 24 December 2020

\section{Introduction}

In simple words, nominee director is neither a staff nor an officer employed by the company; therefore, he stands as a non-executive director in the board of directors of a company. $\mathrm{He}$ is basically nominated to become a board member on behalf of another party outside the company such as stakeholders, investors, or lenders. The question that may arise is whether or not there would be conflict between the nominee director's appointer's interests and the interests of the company. It is highly probable that a nominee director may be put in a complicated position between his appointer and the company's board he is sitting in. Failure to prioritize the interest of the company may lead to a breach of the director's duty. However, it is very crucial for a nominee director to always prefer the company's interests over the appointer's as deliberated in the case of ("Kuwait Asia Bank EC v National Mutual Life Nominees Ltd," 1991). The nominee director must always consider the interests of the company, and not the company's creditors. All directors, including nominee directors must always ask themselves as to whom they owe their duty. According to the case of ("Percival v Wright," 1902) duties are owed to the company as a separate legal entity. It refers to the fiduciary duty to act in good faith in the best interests of the company. It may or it may not be in line with the preference of the shareholders. The common law origin of the duty to act in good faith and for a proper purpose comes from ("Re Smith and Fawcett," 1942) where directors of a company are imposed with legal obligation to always act bona fide in what the board of directors consider to be in the interests of the company, and such duty should not in any way be compromised. The court 
further reiterated that what the court thinks to be in the interests of the company is immaterial.

\section{Materials And Methods}

The aim of this article is to study the legal position in Malaysia, with regard to the duties owed by nominee directors in the event of conflicts of interest that possibly occurs between the company where they are sitting as board members and their appointers. This article employs library based research comprising primary and secondary sources of law. It involves a systematic analysis of statutory provisions and reported case laws that related to the duties of nominee directors in Malaysia. This research adopted qualitative analytical method in which various literatures such as books, article journals, internet sources and other relevant documents are analysed. The statutory provisions of the legislations governing this matter as well as case laws are analysed in order to determine the actual legal position in Malaysia with regard to the duties of nominee directors.

\section{Results And Discussions}

\subsection{Literatures of Various Jurisdictions}

There are numerous literatures discussing the position of nominee director in various jurisdictions. In Australia for example, according to (Baxt, 2005) nominee directors are described as persons who are appointed by various interests to represent them on the board of a company and by virtue of their position, they must always consider in priority of and act in the interests of the company they serve, rather than the interests of their appointer or nominator. The Companies and Securities Law Review Committee portrays the term 'nominee director' as referring to individuals who are required to function independently as members of board of directors, in compliance with stipulated terms of agreement or contract that imposes a duty or reciprocal expectation of fidelity and loyalty to some individual or individuals other than the Company as a whole, regardless of the manner in which the said loyalty is expressed (Panel., 1089). This definition seems to be rather broad, as it covers a case in which the frivolous duty of allegiance is owed to a person who has not played a significant role in nominating or appointing the director as a board member of a company. Nonetheless, it depicts the focal idea that a question appears to happen when such unnecessary obligation of allegiance resides in the directors (Austin, 1995). It has been prevalent practice for investors or shareholders or debenture holders or significant creditors to have control or certain authority in the corporate organization in a form of an express arrangement, either in the organization's constitution or in a type of valuable understanding, for example, a shareholders' agreement, so as to administer the issues involving appointment or removal of a director (Hassan, 2012). With regard to holding and subsidiary companies relationship within a group, it is nothing extraordinary to find a nominee director being appointed by the holding company to sit in the board of its subsidiary. In ("Bennet v. Board of Fire Commissioners of New South Wales NSW ", 1967), it was ruled that nominee director must act in the interests of the company they direct or manage rather than the best interests of the individual who appointed them, as established in the case of ("Scottish Co-Operative Wholesale Society v Meyer ", 1959). A director must exhibit a genuine and honest belief that their action was in the best interests of the company for the duty to act in good faith to be fulfilled. In the case of ("ASIC v Adler," 2002) it is clear that if the interests of the company and the nominating shareholder hinging on such confidential information are not aligned, any disclosure by the nominee director to its nominator may constitute a breach of duty.

In Canada, in the case of nominee directors, they are required to exercise judgment that is independent of the wishes of those responsible for their election or appointment to the board (Reiter, 2006). The dilemma of a nominee director in the case of competing interests of his nominator and the company was also deliberated by (Millard, 1989) where it was highlighted that the principle that directors owe duty to the company and not to his nominator was based on the fundamental notion that fiduciaries must avoid putting themselves in 
position of conflicts, as no man can serves two masters. In the case of ("PWA Corp v. Gemini Group Automated Distribution Systems Inc," 1993), it was highlighted that a director nominated by a particular shareholder of a company is not in any way discharged of his fiduciary duties owed to the company. He must exercise his judgment in the interest of the company and must comply with his duties of disclosures. Further, he must not compromise the interest of the company to those who appointed him. It was held in this case that failure on the part of the nominee director to disclose to the company information relating to its nominator that is vital to the interest of the company had been found to be a breach of his fiduciary duty to the company. In ("820099 Ontarios Incorporation v Harold E Ballard," 1991), the court highlighted that a nominee director must have sufficient courage of conviction to act contrary to the wishes of his appointer if that was towards the best interest of the company requires.

The Company law in the United Kingdom does not distinguish the duties of nominee directors from other types of directorship. All directors owe the same director duties namely the fiduciary duty to act in the best interests of the company. However, when a nominee director is motivated to make decisions which are likely to be significant to the interest of the nominator, this may possibly lead to a conflict between the duties owed by such nominee director to their appointer and the duties they supposed to owe to the company, and this issue can only be determined by considering whether a nominee director is allowed to take into account the interests of the appointer (Ahern, 2010). (Peterson, 2011) nevertheless highlighted that the collision of different concerns of the company which might not be in line with the nominator's or the appointer's should possibly be taken care of and managed, and that the duty to independently and autonomously exercise judgment can be exercised in a flexible and conformable manner without ignoring the company's constitution and this will define the extent to which a nominee director can consider the interests of his appointer in making his decisions as the company's director. In the case of ("Boulting $v$ Association of Cinematograph Technicians," 1963), it was highlighted by Lord Denning that there is nothing amiss with a director being selected and appointed by a shareholder to speak on behalf of the shareholder in the company's board, in so far as the said nominee director is not deprived from exercising his best judgment in light of a legitimate concern for the company which he serves. But if he is put upon terms that he is bound to act in the affairs of the company in accordance with the directions of his patron or appointer, it is beyond doubt unlawful. Further, in the ("Scottish CoOperative Wholesale Society v Meyer," 1959), Lord Denning deliberated that when the interests of two companies (company and corporate nominator) were in strife, the nominee directors were wrong in the event that they put their inclination towards their appointer or nominator in priority, as the interest of the company ought to be the ultimate and primary deciding variable in the course of a decision making exercised by a director.

\section{The Malaysian Law}

In Malaysia, directors are identified not based on the title or designation they are referred to. Instead, they are identified by means of the position they occupy in a corporation by virtue of which his instructions or decisions or directions are to be acted upon (Rahman, Ahamat, \& Ghadas, 2017). This broad description of directors can be found in section 4 of the Companies Act 1965 which also includes an alternate or substitute director. Further, the Companies Act 1965 provides that where a nominee director is removed before the expiration of his office by way of ordinary resolution in a general meeting of a public company, the resolution passed in respect of his removal shall only take effect upon the appointment of his successor. This has been clearly stipulated in section 128 (1) which also indicated an implicit recognition of the position of nominee director in Malaysia.

In August 2006, The Malaysian Corporate Law Reform Committee (CLRC) in August 2006, stated that the phrase 'nominee director' has no legal 
definition, but it is rather being accepted to ascribe as an individual who is "independent of the method of their appointment, in the performance of their office, act in accordance with some understanding, arrangement or status which gives rise to an obligation to the nominator"'(CLRC, 2006). The CLRC (2006) formed a view that nominee directors should be held to a firm and stringent fiduciary duty to act in the best interests of the company. On 15 August 2007, a new section 132(1E) were introduced in the Companies Act 1965 to provide that a director appointed to represent the interests of a shareholder, employer or debenture holder "shall act in the best interest of the company" and in the event of conflict "shall not subordinate his duty to act in the best interest of the company to his duty to his nominator". This provision reflected the position in Malaysia which endorsed a rigorous and stern standard with respect to the duties of nominee directors. One paramount element in respect of the role and service of nominee directors is that he is not empowered to compromise the concern and preference of the company behind his nominator or appointer as his principal. This position is currently maintained with the introduction of section 217 of the Companies Act 2016 ("CA 2016") which states:

"(1) A director who was appointed by virtue of his position as an employee of a company, or who was appointed by or as a representative of a member, employer or debenture holder, shall act in the best interest of the company and in the event of any conflict between his duty to act in the best interest of the company and his duty to his nominator, he shall not subordinate his duty to act in the best interest of the company to his nominator.

(2) A director who contravenes this section commits an offence and shall, on conviction, be liable to imprisonment for a term not exceeding five years or a fine not exceeding three million ringgit or to both."

(Adam, 2016) highlighted that a nominee director is generally appointed to sit as a board member of the company to speak on behalf of a particular class of people, for example, shareholders, a major creditor to the company or an employee group of the company itself.

\section{The Case Analysis}

A nominee director is mainly appointed by his nominator or appointer in order to act as a channel for the appointer to acquire corporate information of the company as well as to represent and safeguard the interest of the appointer or nominator in the company's directors' resolution that form the decision process in the board. In ("Levin v Clark," 1962), Supreme Court of New South Wales, Jacobs J. at pages 700-701 noted as follows:

"It is not uncommon for a director to be appointed to a board of directors in order to represent an interest outside the company: a mortgagee or other trader or a particular shareholder. It may be in the interests of the company that there be upon its board of directors one who will represent these other interests and who will be acting solely in the interest of a third party and who may in that way be properly regarded as acting in the interest of the company as a whole. To argue that a director particularly appointed for the purpose of representing the interest of a third party, cannot lawfully act solely in the interest of that third party, is in my view to apply the broad principle, governing the fiduciary duty of directors, to a particular situation, where the breadth of the fiduciary duty had been narrowed by agreement amongst the body of shareholders."

There are several local cases that illustrate the duties owed by the nominee directors and the conflicts they encountered.

The first one is the case of ("Mohd Shuaib Ishak v Celcom (M) Bhd ", 2008). In this case, the plaintiff was a former member of the corporation who decided to cease from being a member and a shareholder due to the reason that his shares were being compulsorily purchased under section 34 of the Securities Commission Act 1993. He was determined to commence and file a statutory derivative proceeding against several parties, and one of the named defendants were the directors of the company, namely Celcom. The plaintiff was a shareholder of Celcom. The plaintiff impeached 
that the defendants connived to impel Celcom to renege on the covenants under an Amended and Restated Supplemental Agreement (ARSA) entered between Celcom and DeTeAsia and two more different companies. By this agreement, Celcom was then bound not to fuse its commercial and corporate activities and dealings or accede any extensive new shareholder beyond sanction of DeTeAsia, otherwise, Celcom would assure a Buy Out Offer for DeTeAsia for a value of RM7 for every share in Celcom which was owned by DeTeAsia. Telekom Malaysia (TM), Telekom Enterprise Sdn Bhd (TESB) and their parties acting in concert propounded to amalgamate Celcom's business with Telekom's cellular business through merger and consolidation, and takeover Celcom. Over and above this aim, TM which by then has sufficient and significant control of and authority over Celcom, led Celcom to venture into a sale and purchase agreement (SPA) through which Celcom approved to retain $100 \%$ of TM's interest through shareholdings in TM Cellular Sdn Bhd from TM. The plaintiff also denounced that these parties benefitted from the conspired plan with the directors of Celcom. In that situation, Celcom became the sole and primary chump as Celcom consequently were imposed with penalty favouring DeTeAsia while TM, TESB and parties acting in concert emerged as the biggest winners from the malfeasance when they eventually completed their attempt to take over Celcom at an approximately low price. In this case, the Court held that the directors of Celcom clearly owed their duty to the company. In its judgment, the Court ruled that the directors also owed explanation to its shareholders. They are mandated by the company to decide in the interests of Celcom and to better direct both Celcom and its shareholders. They are obliged to report the information, facts and problems related to the Sales and Purchase Agreement (SPA) and the Mandatory General Offer (MGO) in a comprehensible and concise manner. They also owed a duty to look after the interests of the shareholders and not to misinform them about both the Buy Out and the ARSA. They must also somehow have the interests of the shareholder at mind to allow them to secure the best price for the shares. The fiduciary duty to act in good faith in the interests of the company as a whole requires the directors to act as a collective group in the best interests of the shareholders. Nevertheless, the Court also went on to point out that complications come into play in circumstances where a nominee director is nominated to serve the interests of specific persons (persons with such a major stake in the company may sometimes nominate someone they confide to the Board to control their operations, i.e. TM). The intent of nominating nominee directors would be to act as representatives and in the interest of their appointers or nominators rather than the members generally.

Since a nominee director is assigned to represent the appointer's or nominator's interest in a business, he has a responsibility to protect and uphold the nominator's or appointer's stake and position unless it clashes with the company's stake and interests (Hassan, 2012). With this regard, the director assumes the role of 'watch dog' for the nominator or appointer, surveilling and supervising the actions, performances and expansions of the company's investment and operations, which would otherwise be not viable. Nevertheless, a nominee director is considered to be in conflict when he breached his fiduciary duty towards the company he is sitting, in the course of him acting in loyalty towards his nominator.

In the recent case of ("Yeoh Seng Keong v Bircher Asia Pacific Sdn Bhd," 2018), the High Court and Court of Appeal had taken the responsibility to illuminate on the question involving the duty of nominee director namely with regard to the directors' responsibilities in practice. A nominee director claimed in view of his appointment as a nominee director, he therefore was not conferred the capacity of an actual director and would have not been able to serve his mangerial or directorial functions and duties to the company. In delivering its judgment, the High Court highlighted that it is of no consequence that the director had referred himself as a 'nominee director'. The court further emphasized that Companies Act did not 
differentiate between the types of directors and their corresponding obligations; it simply imposed the same obligations on a 'director' which would include 'nominees' as well as those who act in a capacity accustomed to directors regardless of title. Therefore, he was considered a director which is recognised by the law to owe fiduciary duties to the plaintiff company.

Similar position can also be seen in the case of Dato' Seri Timor Shah Rafiq v Nautilus Tug \& Towage Sdn Bhd, where (Celcom, 2008) at page 412 stated that:

"The law, as so clearly encapsulated in ss $131 B$ and 132 of the CA does not make a distinction on the powers and duties of company directors on the basis of nationality, residence, or whether the director is performing an executive role or otherwise, or whether the director is a nominee or a corporate representative of a shareholder. ... Directors of a company enjoy the same right of inspection under the law. The law admits of no distinction between the statutory and fiduciary duties owed by different categories of directors."

The High Court and Court of Appeal judgments demonstrate that there is no difference between 'nominee' directors and actual directors as deliberated by the Companies Act 2016. An individual assumes the office of director when he is appointed to sit and perform his function as a board member of the company. It does not matter if he is appointed by the board, nominator or shareholders. The fact that he carries on his duty in the board and receives certain remuneration at the same time, make him bound to the fiduciary duty towards the company.

Just as similar to all other directors of a company's board, nominee directors are at all times expected, to ultimately exercise its duty towards protecting the company's ethereal concern and importance being the reason of their appointment and also, they owe the equal legal fiduciary duties to the company as all other directors do. Further, nominee directors are expected by the appointers, being the stakeholder of the company, to habitually apprise on the performance of the company. This means a nominee director has to communicate certain information of the company to a person outside the board. In addition, the nominee directors also represent the voice of the appointers or nominators in respect of the company's commercial, business and management decisions. In this regard, it is conventionally and legally recognised that everyone sitting in the company's board of directors (which includes nominee directors) should be allowed with or given access to all records and information of the company in order to facilitate the directors to serve and carry out their functions and duties in the board (as established in the case of ("Yeoh Seng Keong v Bircher Asia Pacific Sdn Bhd," 2018), unless it is apparent or evident that such access of company's information may expose the company to certain legal risks, such as that the director will abuse or manipulate them, especially when it comes to internal records as well as confidetial and sensitive data belonging to the company (Hassan, 2012). Should there be a clash or disagreement between both the duties of the nominee director on either the company or its nominator or appointer, that director should therefore eliminate the possibility of occurrence of such conflict or attempt his best to mitigate such risk. This is the reason why such director needs to always reflect whether or not each decision he takes or act he does, legally breach his duty to the company.

\section{CONCLUSION}

The reality is that nominee directors constantly faced with apparent conflict of interest, as they are commercially expected to act for their appointers yet the law at the same time imposes the duty on them to always act for the company and in the best interest of the company above any of the interests of their nominator or appointer. The Company Law does not distinguish the duties of nominee directors from other types of directorship. All directors, irrespective of their status as a nominee or otherwise, owe the same director duties namely the fiduciary duty to always act for the company and it must be in the best interests and in favour of the company. However, when a nominee director is 
motivated to make decisions which are likely to be welfare-enhancing for their appointer or nominator, there is a likelihood that it may lead to competition of interests namely the interests on the part of the company as well as the interests of the part of the nominator or appointer. If such competition occurs and the interest of the company is compromised, that would be considered as a conflict which lead to breach or infringement of the duty of the director to the company. Therefore, it is very pertinent for such issue to be resolved by considering whether a nominee director is in the position to consider or entitled to scrutinize and contemplate the interests of the appointer. A nominee director can not in any circumstances breach his fiduciary duty towards his company in the course of his loyalty towards his nominator.

\section{REFERENCES}

[1] 820099 Ontarios Incorporation v Harold E Ballard. (1991). 3 WLR (2nd) 113

[2] Adam, Y. C. (2016). corporate governance anD nominee Directors-What Does it mean? Management \& Accounting Review (MAR), 15(2), 171-184. http://arionline.uitm.edu.my/ojs/index.php/ MAR/article/view/594

[3] Ahern, D. M. (2010). 'Nominee Directors' Duty to Promote the Success of the Company: Commercial Pragmatism and Legal Orthodoxy'.

[4] ASIC v Adler. (2002), from NSWSC 171

[5] Austin, R. (1995). Representatives and Fiduciary Responsibilities-Notes on Nominee Directorships and Life Arrangements. Bond L. Rev., 7, i.

[6] Baxt, R. (2005). Duties and responsibilities of directors and officers: AICD.

[7] Bennet v. Board of Fire Commissioners of New South Wales NSW (1967). 87WN NSW 307

[8] Boulting v Association of Cinematograph Technicians. (1963). 2 QB 606

[9] Celcom, M. S. I. v. (2008). MLJ 857. .

[10] Hassan, H., Ghadas, Z.A.A., Rahman, N.A. . (2012). The Myth of corporate personality': A comparative legal analysis of the doctrine of corporate personality of Malaysian and Islamic laws, Australian Journal of Basic and Applied Sciences 6(11), pp. 191-198.

[11] Kuwait Asia Bank EC v National Mutual Life Nominees Ltd. (1991). 1 AC 187 PC

[12] Levin v Clark. (1962). NSWR 686

[13] Millard, J. A. (1989). The Responsible Directors. Toronto. Canada: Carswell.

[14] Mohd Shuaib Ishak v Celcom (M) Bhd (2008). 5 MLJ 857.

[15] Panel., A. G. T. o. (1089). Companies And Securities Law Review Committee Nominee Directors And Alternate Directors. Report No.8. 2 March 1989, , from retrieved from https://www.takeovers.gov.au/content/Res ources/cslrc/cslrc_report_no_8.aspx

[16] Percival v Wright. (1902). 2 Ch 401

[17] Peterson, S. (2011). Nominee Directors and Insolvent Companies. Slaughter and May (July 2011): 1-9, retrieved from https://www.slaughterandmay.com/media/ 1555668/nominee-directors-and-insolventcompanies.pdf.

[18] PWA Corp v. Gemini Group Automated Distribution Systems Inc. (1993). 8 BLR (2d) 221

[19] Rahman, N., Ahamat, H., \& Ghadas, Z. (2017). The Theory of Harm under the Malaysian Competition Act 2010. PERTANIKA JOURNAL OF SOCIAL SCIENCE AND HUMANITIES, 25, 155165.

[20] Re Smith and Fawcett. (1942). Ch 304

[21] Reiter, B. J. (2006). Directors' duties in Canada: CCH Canadian Limited.

[22] Scottish Co-Operative Wholesale Society v Meyer (1959). AC 324

[23] Yeoh Seng Keong v Bircher Asia Pacific Sdn Bhd. (2018). MYCA 260. 